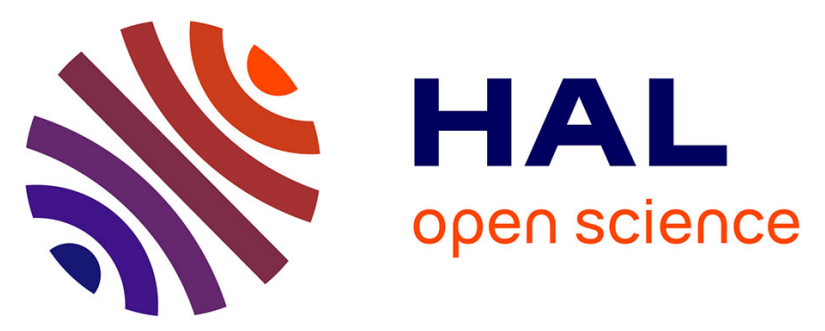

\title{
AIRE GENE MUTATIONS AND AUTOANTIBODIES TO INTERFERON OMEGA IN PATIENTS WITH CHRONIC HYPOPARATHYROIDISM WITHOUT APECED
}

Sara Cervato, Luca Morlin, Maria Paola Albergoni, Stefano Masiero, Nella Greggio, Cristiano Meossi, Shu Chen, Jadwiga Furmaniak, Bernard Rees Smith, Mohammad Alimohammadi, et al.

\section{- To cite this version:}

Sara Cervato, Luca Morlin, Maria Paola Albergoni, Stefano Masiero, Nella Greggio, et al.. AIRE GENE MUTATIONS AND AUTOANTIBODIES TO INTERFERON OMEGA IN PATIENTS WITH CHRONIC HYPOPARATHYROIDISM WITHOUT APECED. Clinical Endocrinology, 2010, 73 (5), pp.630. 10.1111/j.1365-2265.2010.03862.x . hal-00583577

\section{HAL Id: hal-00583577 https://hal.science/hal-00583577}

Submitted on 6 Apr 2011

HAL is a multi-disciplinary open access archive for the deposit and dissemination of scientific research documents, whether they are published or not. The documents may come from teaching and research institutions in France or abroad, or from public or private research centers.
L'archive ouverte pluridisciplinaire HAL, est destinée au dépôt et à la diffusion de documents scientifiques de niveau recherche, publiés ou non, émanant des établissements d'enseignement et de recherche français ou étrangers, des laboratoires publics ou privés. 


\section{CLINICAL ENDOCRINOLOGY}

\section{AIRE GENE MUTATIONS AND AUTOANTIBODIES TO INTERFERON OMEGA IN PATIENTS WITH CHRONIC HYPOPARATHYROIDISM WITHOUT APECED}

\begin{tabular}{|r|l|}
\hline Journal: & Clinical Endocrinology \\
\hline Manuscript ID: & CEN-2009-000886.R2 \\
\hline Manuscript Type/Office: & 1 Original Article - UK/Europe \\
\hline Dute Submitted by the & 27-Jul-2010 \\
\hline Complete List of Authors: & $\begin{array}{l}\text { Cervato, Sara; University of Padua, Medical and surgical sciences } \\
\text { Morlin, Luca; University of Padua, Medical and Surgical Sciences } \\
\text { Albergoni, Maria Paola; Blood Transfusion Center, Azienda } \\
\text { Ospedaliera-Università di Padova } \\
\text { Masiero, Stefano; Endocronilogy Unit, Medical and Surgical Sciences } \\
\text { Greggio, Nella; Padova University, Department of Pediatrics } \\
\text { Meossi, Cristiano; Ospedale di Lucca, Divisione di Pediatria } \\
\text { Chen, Shu; FIRS Laboratories, RSR Ltd } \\
\text { Furmaniak, Jadwiga; RSR Ltd, FIRS Laboratories } \\
\text { Rees Smith, Bernard; RSR Ltd, FIRS Laboratories } \\
\text { Alimohammadi, Mohammad; Uppsala University, Department of } \\
\text { Medical Sciences } \\
\text { Kämpe, Olle; Uppsala University, Department of Medical Sciences } \\
\text { Betterle, Corrado; University of Padua, Medical and Surgical } \\
\text { Sciences }\end{array}$ \\
\hline Key Words: & $\begin{array}{l}\text { chronic hypoparathyroidism, , AIRE gene mutations, Class II HLA, } \\
\text { Autoimmune diseases, Autoimmune polyendocrine syndromes }\end{array}$ \\
\hline
\end{tabular}

\section{SCHOLARONE




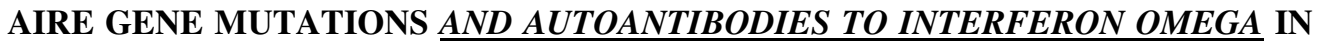 \\ PATIENTS WITH CHRONIC HYPOPARATHYROIDISM WITHOUT APECED \\ (3508 Words). \\ *Sara Cervato, * Luca Morlin, "Maria Paola Albergoni, ${ }^{*}$ Stefano Masiero, ${ }^{* *}$ Nella \\ Greggio, “Cristiano Meossi, ^Shu Chen, ^Maria del Pilar Larosa, ^Jadwiga Furmaniak, \\ ^Bernard Rees Smith, ${ }^{\circ}$ Mohammad Alimohammadi, Ole Kämpe, ${ }^{\S}$ Mariella Valenzise, \\ and * Corrado Betterle
}

\author{
*Department of Medical and Surgical Sciences, and \\ ** Department of Pediatrics, Padova University, Padova, Italy \\ = Blood Transfusion Center, Azienda Ospedaliera-Università di Padova, Padova, Italy \\ “Divisione di Pediatria, Ospedale di Lucca, Lucca, Italy \\ ^FIRS Laboratories, RSR Ltd, Cardiff, UK \\ ${ }^{\S}$ Department of Pediatrics University of Messina, Messina, Italy \\ 'Department of Medical Sciences, Uppsala University Hospital Uppsala, Sweden
}

Key Words: chronic hypoparathyroidism, AIRE gene mutations, Class II HLA, Autoimmune diseases, Autoimmune polyendocrine syndromes, interferon omega antibodies.

Running Title: AIRE gene mutations in chronic hypoparathyroidism

\author{
Corresponding Author: \\ Corrado Betterle MD, \\ Department of Medical and Surgical Sciences, \\ Padova University, Padova Italy \\ Via Ospedale Civile 105, 35100, \\ Padova, Italy \\ Tel: +390498213014 \\ Fax: +39049657391 \\ E-mail: corrado.betterle@unipd.it
}




\section{SUMMARY (243 words) \\ Objective:}

To assess autoimmune regulator (AIRE) gene mutations, class II HLA haplotypes, and organ or non-organ specific autoantibodies in patients with chronic hypoparathyroidism $(\mathrm{CH})$ without associated Addison's disease (AD) or chronic candidiasis (CC).

\section{Design, Patients and Measurements:}

24 patients who had $\mathrm{CH}$ without $\mathrm{AD}$ or $\mathrm{CC}$ were included in the study. AIRE gene mutations in all 14 exons were studied using PCR in 24 patients, 105 healthy controls and 15 firstdegree relatives of $\mathrm{CH}$ patients with AIRE mutations. HLA were determined for all 24 patients and 105 healthy controls. Autoantibodies to a range of antigens including NACHT leucine-rich-repeat protein5 (NALP-5) and interferon omega (IFN patients.

\section{Results:}

AIRE gene mutations were found in 6/24 (25\%) patients, all females, and this was significantly higher $(\mathrm{p}<0.001)$ compared with AIRE mutations found in healthy controls (2/105). Three patients (12.5\%) had homozygous AIRE mutations characteristic of APECED and all three were also positive for IFN heterozygous AIRE mutations; two of these were novel mutations. One of the patients with heterozygous AIRE mutations was positive for both NALP5 and IFN a autoantibodies. Heterozygous AIRE mutations were found in 10/15 first-degree relatives of $\mathrm{CH}$ patients with AIRE mutations although none was affected by $\mathrm{CH}$. Class II HLA haplotypes were not statistically different in patients with $\mathrm{CH}$ compared to healthy controls.

\section{Conclusions:}




\section{Page 3 of 23}

Clinical Endocrinology

Analysis of AIRE gene mutations together with serum autoantibody profile should be helpful
in the assessment of patients with $C H$ in particular in young women with associated
autoimmune diseases. 


\section{INTRODUCTION (3508 Words)}

Autoimmune-Poly-Endocrinopathy-Candidiasis-Ectodermal-Dystrophy (APECED) (1), or autoimmune polyendocrine syndrome type 1 (APS-1) (2), is characterized by the presence of at least two of three conditions:- chronic candidiasis $(\mathrm{CC})$, chronic hypoparathyroidism $(\mathrm{CH})$ and Addison's disease (AD). APECED is a monogenic autosomal recessive disease associated with mutations in the autoimmune regulator (AIRE) gene and associations of APECED with HLA genes are not generally found $(\mathbf{3}, \mathbf{4}) . \mathrm{CH}$ is the most common disease in APECED, found in 71-100\% of 385 reviewed patients (5). APECED presents in childhood with $\mathrm{CH}$ usually preceded by $\mathrm{CC}$ and followed by $\mathrm{AD}(\mathbf{3}, \mathbf{4})$. Recently, it has been shown that serum autoantibodies (Abs) to interferon omega $(I F N \omega)(6)$ are characteristic of APECED and Abs to NACHT leucine-rich-repeat protein 5 (NALP5) are characteristics of $\mathrm{CH}$ in patients with APECED (7).

$\mathrm{CH}$ can also occur in an isolated (idiopathic) form, or in combination with autoimmune diseases other than $\mathrm{CC}$ and/or $\mathrm{AD}(\mathbf{5}, \mathbf{8}, \mathbf{9})$. An association of isolated $\mathrm{CH}$ with Class II HLA genes has been reported (10) however an association with AIRE gene mutations has not been found (11).

In this study we analysed AIRE mutations, HLA type and autoantibody profiles in a group of Italian patients with $\mathrm{CH}$ who showed no clinical signs of $\mathrm{CC}$ or $\mathrm{AD}$ at presentation.

\section{MATERIAL AND METHODS}

\section{PATIENTS}

Out of 102 Italian patients with $\mathrm{CH}$ who were initially referred to our clinic, 78 had $\mathrm{CH}$ associated with $\mathrm{CC}$ and/or $\mathrm{AD}$ and consequently were classed as APECED, while 24 had isolated $\mathrm{CH}$ or $\mathrm{CH}$ associated with autoimmune diseases other than $\mathrm{CC}$ or $\mathrm{AD}$. At entry to the 
study all 24 patients had low serum calcium and elevated serum phosphorus levels with low levels of PTH and were receiving substitutive therapy with vitamin D and calcium.

AIRE gene mutations, class II HLA type and serum autoantibodies were analysed in 24 patients who were included in the study. 15 first-degree relatives of patients with $\mathrm{CH}$ who had AIRE gene mutations were also studied. The study was approved by the Local Ethical Committee, and patients gave their written consent for the study.

\section{AIRE GENE MUTATION ANALYSIS}

All 14 exons of the AIRE gene and their flanking exon-intron boundaries (GenBank accession no. Aj009610) were analysed in the 24 patients, in 15 first-degree relatives, and in 105 healthy adult controls using the methods described previously (12). PCR amplifications were performed in a Verity thermal cycler (Applied Biosystems) using the specific primers for each exon (shown in Table 1). Typically, PCR amplification from $200 \mathrm{ng}$ of genomic DNA was carried out in 35-cycles of: an initial 10 -min denaturation at $95^{\circ} \mathrm{C}$ followed by 30 sec at $95^{\circ} \mathrm{C}$, annealing at $55-63^{\circ} \mathrm{C}$ for $30 \mathrm{sec}$ (Table 1), and final extension at $72^{\circ} \mathrm{C}$ for $30 \mathrm{sec}$ in a $25 \mu \mathrm{L}$ total volume containing a $10 \mathrm{x}$ buffer solution, $0.2 \mathrm{mmol} / \mathrm{L}$ of each dNTP (dATP, dGTP, dCTP, dTTP), $2.5 \mathrm{mmol} / \mathrm{L} \mathrm{MgCl}, 0.4 \mathrm{pmol} / \mu \mathrm{L}$ of each primer and $5 \mathrm{U} / \mu \mathrm{L}$ of Taq Gold. For CG-rich exons 50\% deaza-GTP (Sigma Aldrich Co., St.Louis, Missouri) were used instead of dGTP. In the reactions for exons 1, 2 and 14, 5\% dimethyl sulfoxide was added to aid amplification reactions. PCR products were separated from the primers and excess nucleotides using a Microcon unit (Millipore), quantified and sequenced using a direct chain termination method with BigDye Terminator v1.1 Cycle Sequencing Kits (PE Applied Biosystems Milan, Italy). Sequencing reaction products were purified using the Microcon (Millipore), and analyzed on an automated DNA sequencer (ABI PRISM 310, Genetic Analyzer, Applied Biosystems). 


\section{CLASS II HLA TYPING}

Human leukocyte antigens (HLA)-DRB1 were determined in 24 patients, and in 105 healthy adult controls randomly selected from the Bone Marrow Donor Register PD02. DNA was extracted from $400 \mu \mathrm{L}$ of peripheral blood using a QIAamp DNA minikit (QIAGEN, Crawley, UK). HLA typing was carried out using PCR-SSP (PCR sequence-specific primers) (GenoVision, Philadelphia, PA). For each sample, 23 PCRs were performed and the amplification products were stained with ethidium bromide and analyzed on $2 \%$ agarose gel using standard procedures (13).

\section{STATISTICAL ANALYSIS}

The phenotype frequency was calculated using the number of individuals carrying the allelic group and compared with the total number of individuals. Differences in the frequency of HLA DRB1 allele groups between $\mathrm{CH}$ patients and healthy controls were assessed using Fisher's exact test, and a $\mathrm{p}<0.05$ was considered significant.

\section{AUTOANTIBODY TESTS}

Sera from the 24 patients with isolated $\mathrm{CH}$ and $\mathrm{CH}$ associated with autoimmune diseases other than $\mathrm{CC}$ and/or $\mathrm{AD}$ were tested for autoantibodies to: thyroid microsomal antigen (TMHAbs), thyroglobulin (TgHAbs), parietal-cells (PCA), intrinsic factor (IFA), adrenal cortex (ACA), steroid 21- hydroxylase (21-OHAbs), steroid-producing cell (StCA), islet-cells (ICA), glutamic acid decarboxylase (GADAbs), second islet antigen (IA2Abs), nuclear proteins (ANA), mitochondria (AMA), liver-kidney microsomes (LKMA), NALP5, and IFN $\omega$.

In particular, TMHAbs and TgHAbs were tested by haemagglutination method using kits from Remel Inc. (Santa Fe, USA). PCA, ICA, ACA, StCA, ANA, AMA, and LKMA were tested using the classical indirect immunofluorescence test on human or animal tissues as previously described (14). IFA were tested using an ELISA (EUROIMMUN AG. Lubeck, 
Germany). 21-OHAbs were measured by the method described by Tanaka (15) using reagents from RSR Ltd, Cardiff (UK). GADAbs and IA2Abs were determined in a radioimmunoassay using kits from RSR Ltd, Cardiff (UK). NALP5Abs were measured using an immunoprecipitation assay based on ${ }^{35}$ S-labelled NALP5 as described by Alimohammadi (6). IFN $\omega$ Abs were tested using an immunoprecipitation assay based on ${ }^{35}$ S-labelled IFN $\omega$ produced using an in vitro transcription/ translation method with rabbit reticulocytes (Promega, Southampton, UK). Human IFN $\omega$ cDNA (16) was synthesised in vitro (GeneArt $A G$, Regensburg, Germany) with a 5'-prime EcoR I and a 3-prime Xba I restriction site for direct cloning into $p$ TnT vector (Promega). In the assay $5 \mu \mathrm{L}$ of test serum in duplicate were incubated with $50 \mu \mathrm{L}$ of ${ }^{35} \mathrm{~S}$-IFN (30,000dpm) overnight at $2-8^{\circ} \mathrm{C} .50 \mu \mathrm{L}$ of Protein A suspension was then added and the incubation continued for 1 hour at $2-8^{\circ} \mathrm{C}$. The precipitates were washed 3 times and counted in a $\beta$ counter. The cut off for positive results was based on 99th percentile of individual controls studied.

\section{RESULTS}

\section{CLINICAL AND IMMUNOLOGICAL STUDY}

Clinical characteristics of the 24 patients and results of genetic and serum autoantibody tests are summarized in Table 2. The mean age at onset of $\mathrm{CH}$ in these patients was 23.2 years and the $\mathrm{F} / \mathrm{M}$ ratio was $3.8 / 1$.

\section{AIRE GENE MUTATIONS AND AUTOANTIBODIES}

Analysis of the AIRE gene revealed the presence of mutations in 6 out of $24(25 \%)$ patients (patients 2, 3, 4, 9, 12, 14; Table 2) and in 2 out of 105 healthy Italian controls $\underline{\text { (data }}$ not shown). The prevalence of AIRE gene mutations was significantly higher $(p<0.001)$ in patients with $\mathrm{CH}$ compared to healthy controls. Out of 6 patients with AIRE mutations 4 were positive for IFN $\omega$ Abs (Table 2).

AIRE gene mutations were found in $6 / 19$ females (31.6\%) and in 0/5 males (0\%). 5/17 patients (29.4\%) with $\mathrm{CH}$ associated with the presence of autoantibodies or autoimmune 
diseases other than AD or CC had AIRE gene mutations while only $1 / 7$ patients $(14.2 \%)$ with $\mathrm{CH}$ without autoimmune diseases or autoantibodies had AIRE gene mutations.

Specifically 2 patients had homozygous mutations: R257X/R257X in exon 6 (patient 2, Table 2) and $W 78 R / W 78 R$ in exon 2 (patient 4, Table 2) and one patient had a combined mutation $\underline{(R 203 X}$ in exon 5 associated with IVS9+5G>T in exon 8 (patient 3, Table 2). These mutations have been described in patients with APECED previously $(12,18,19)$. In the case of these three patients the mean age at onset of $\mathrm{CH}$ was 3.3 years. These three patients were positive for IFN $\omega$ Abs (patients 2, 3, and 4, Table 2).

Heterozygous mutations were found in three patients, there were two novel mutations: D312N in exon 8 (patient 9, Table 2), and R471C in exon 12 (patient 14, Table 2), while the third patient (patient 12, Table 2) had a mutation P526L in exon 14 reported to be associated with APECED in homozygous presentation previously $(12,17)$. One of the three patients who carried the heterozygous mutations was positive for NALP5Abs and IFN A Abs (patient 9, Table 2). The mean age at onset of $\mathrm{CH}$ in three patients who carried the heterozygous mutations was 20 years, whereas in the patients who had no AIRE gene mutations this was 27.3 years.

Heterozygous mutations $R 257 X$ and C322fs 372 were found in two healthy controls in this study. The healthy controls that were found to carry AIRE gene mutations showed no evidence of clinical or latent autoimmune diseases.

In the course of our study we have noted a novel sequence variant in exon 6 (G218) not associated with an amino acid change in one healthy control. In addition, a number of known AIRE gene polymorphisms were found in patients with $\mathrm{CH}$ (Table 2).

\section{CH PATIENTS WITH AIRE GENE MUTATIONS}


Patient 2 (Table 2) was a female of Venetian origin who had R257X homozygous mutation in exon 6 characteristic for APECED patients from this region (12). She developed $\mathrm{CH}$ at 2 years of age and after presenting with primary amenorrhea at 14 years of age she was diagnosed with a hypergonadotropic hypogonadism with a normal female karyotype. Serum autoantibody tests carried out when she was 21 years old were all negative except for IFN $\omega$-Ab which was positive. Both parents had heterozygous AIRE gene mutation (R257X) without clinical, latent or potential autoimmune diseases. The patient's brother had no AIRE gene mutations or autoimmune diseases (Table 3).

Patient 3 (Table 2) was a female from Sicily who developed $\mathrm{CH}$ at 4 years of age and who carried two AIRE mutations (R203X in exon 5 and IVS9+5G>T in exon 8). The R203X mutation is typically found in APECED patients from Sicily $(\mathbf{1 2 , 1 8})$ while IVS9+5G $>$ T mutation has been described to date in only one patient with APECED from Sardinia (19). Patient 3 tested positive for IFN $\omega$ Abs, however to date has not yet developed either CC or other clinical, subclinical or potential autoimmune diseases in the few months of follow up. The patient's mother carried the heterozygous mutation R203X but had no clinical or latent autoimmune diseases; the father had the heterozygous mutation IVS9+5G>T and had been diagnosed with chronic thyroiditis. The brother and one sister both had heterozygous mutation IVS9+5G>T without clinical, subclinical or potential autoimmune diseases while the other sister did not have AIRE gene mutations or clinical, subclinical or potential autoimmune diseases (Table 3).

Patient 4 (Table 2) was a female of Tuscan origin with homozygous mutation W78R in exon 2 found in APECED patients from Apulia (12, 23). She developed $\mathrm{CH}$ at 4 years of age and at that time had no CC or other clinical autoimmune diseases. However, when she was 5 years old she tested positive for serum ACA (high titre of 1:32) and for 21-OHAbs (55U/mL) with a normal adrenal function in the ACTH test. At 6 years of age during an episode of acute 
infection she developed adrenal insufficiency, was started on substitutive steroid hormone therapy and has remained on substitutive steroids ever since. A serum sample taken following the adrenal crisis episode was positive for ACA, 21-OH Abs and INFW Abs. Patient 4's mother had a heterozygous W78R mutation and suffered from chronic thyroiditis while the father who also carried heterozygous W78R mutation had no clinical, latent or potential autoimmune diseases (Table 3).

Patient 9 (Table 2) was a female of Venetian origin and carried a novel AIRE gene mutation characterized by the substitution of an aspartic acid at position 312 by an asparagine (D312N in exon 8) in the AIRE gene region coding for the plant homeodomain (PHD). As reported before, a missense mutation in the PHD results in increased localisation of AIRE to the cytoplasm and decreased transcriptional transactivation activity (20). This patient developed chronic thyroiditis with subclinical hypothyroidism at 7 years of age and was treated with Lthyroxine. When she was 14 years old she developed $\mathrm{CH}$ with serum NALP5Abs positivity and was treated with vitamin D and calcium. Also at the age of 14 years she tested positive for ICA at $80 \mathrm{JDF} / \mathrm{Units}$ and GADAbs at $755 \mathrm{U} / \mathrm{mL}$ although had a normal glucose tolerance test at that time. She has maintained ICA and GAD Abs positivity without the evidence of glucose intolerance during follow up to date ie until the age of 21 years). At the age of 20 years she was tested and found positive for INF $\omega$ Abs. Her father also had heterozygous mutation (D312N) and he was positive for serum thyroid autoantibodies with a normal thyroid function and positive for GADAbs with normal glucose tolerance. The mother had no mutations in the AIRE gene but had chronic thyroiditis with hypothyroidism and was on therapy with L-thyroxine. She was also positive for GADAbs with normal glucose tolerance. In contrast, the patient's sister did not have AIRE gene mutations or clinical, latent or potential autoimmune diseases (Table 3). 
Patient 12 (Table 2) was female with a mutation characterized by the substitution of proline at position 526 by leucine (P526L in exon 14) (17). The patient developed $\mathrm{CH}$ when she was 20 years old and to date (at 75 years of age) she has not shown clinical signs of other autoimmune diseases, however she has detectable serum PCA and IFA with high plasma gastrin levels and normal blood count. This condition is highly suggestive of autoimmune gastritis (AG), however the patient has refused further investigations in particular a gastroscopy. Her parents were not available for testing AIRE gene mutations but they had a negative history for autoimmune diseases.

Patient 14 (Table 2) was a female of Venetian origin and she carried a novel missense mutation characterized by the substitution of arginine at position 471 by cysteine (R471C in exon 12). This mutation resides in one of the zinc fingers of the AIRE PHD which is known to be involved in chromatin-mediated regulation of transcription (21). The patient developed psoriasis at 20 years of age, transient diabetes insipidus at 24 years of age, $\mathrm{CH}$ and chronic thyroiditis at 26 years of age. When she was 30 years old she tested positive for PCA with normal blood count and normal plasma gastrin levels. The patient's mother had R471C mutation with no evidence of clinical autoimmune diseases however was found positive for PCA on autoantibody screening. The father had no AIRE gene mutations and had no clinical, subclinical or potential autoimmune diseases however he suffered from lung cancer (Table 3).

\section{HLA ANALYSIS}

The results of HLA typing in 24 patients with $\mathrm{CH}$ are summarized in Table 2. The prevalences of class II HLA haplotypes in patients with $\mathrm{CH}$ compared to healthy controls were not statistically significantly different $(\mathrm{p}>0.05)$. 


\section{DISCUSSION}

We studied a group of Italian patients who presented with non familial sporadic $\mathrm{CH}$ on its own or associated with autoimmune conditions other than $\mathrm{CC}$ and/or AD. The mutations in all exons of the AIRE gene, class II HLA phenotype and serum autoantibody profiles were studied in all patients. We found homozygous or heterozygous AIRE gene mutations in six females $(25 \%)$ who presented with $\mathrm{CH}$ at a young age (below the age of 26 years). 4/6 patients with AIRE mutations had associated autoimmune diseases other than $\mathrm{AD}$ or $\mathrm{CC}$ and/or tested positive for serum autoantibodies (Table 2). However, 2/6 $\mathrm{CH}$ patients who carried AIRE mutations have not shown signs of autoimmunity as yet. Autoantibodies to

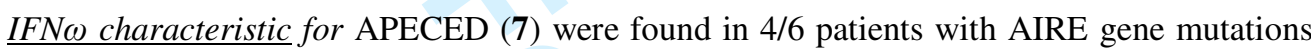
but in none of the patients without mutations.

In contrast patients without AIRE gene mutations were prevalently males, developed $\mathrm{CH}$ at an older age, and did not present either clinical autoimmune disorders or autoantibodies $\underline{i n}$ particular IFN $\mathrm{A}$ Abs.

Our observations differ from the results of a previous study in which AIRE gene mutations had not been found in any of the patients with isolated $\mathrm{CH}$ (11). However in that study (11) only a limited number of the AIRE gene exons (exons 2, 6 \& 8) were analysed for mutations while in our study all 14 exons were assessed. In particular in our study the mutations were found in AIRE gene exons 2, 5, 6, 8, 12 and 14.

Three $\mathrm{CH}$ patients had homozygous AIRE gene mutations (12.5\%) that were described previously and are typically found in APECED patients in Italy (12, 18, 19, 23, 24). Furthermore, all these three had detectable serum IFN 1 Abs. Consequently these patients may be considered to be at risk of developing complete APECED syndrome in the future. 
Indeed, one of these (Patient 4, Table 2) developed clinical AD 2 years after the start of the follow up and 1 year after ACA positivity was first detected at autoantibody screening. This is consistent with our previous observations that the presence of ACA/21-OHAbs in patients with $\mathrm{CH}$ is associated with a risk of developing $\mathrm{AD}$ within a few months from the time when autoantibodies were first detected (25). Another patient with combined AIRE gene mutations and positive serum IFN $\omega$ Abs (Patient 2; Table 2) who developed hypergonadotropic hypogonadism at the age of 14 years, to date at the age of 21 years, has no signs of $\mathrm{CC}$ or $\mathrm{AD}$ and is also negative for adrenal cortex autoantibodies. However, as she carries the AIRE gene

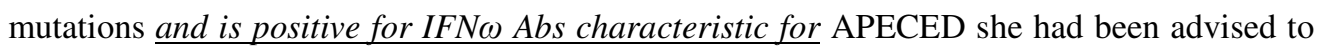
have the ACA test annually. The third patient, a 4 year old female with AIRE gene mutations and positive serum IFN $\omega$ Abs (Patient 3; Table 2) is negative for ACA and has no clinical signs of $\mathrm{AD}$ or $\mathrm{CC}$. So far she has been followed-up for only one year and it is planned that serum ACA and the signs of CC will be assessed on an annual basis in future.

Follow up of the patients described above could be relevant for their clinical outcomes, particularly in view of reports that the detection of homozygous AIRE gene mutations in patients with one manifestation of APECED (for example isolated autoimmune AD) may be helpful in identification of patients with hitherto unidentified APECED (26, 27). More recently it has also been observed that finding AIRE gene mutations in some patients who did not meet the criteria of APECED indeed helped to identify those with APECED (27).

In addition, three of our $\mathrm{CH}$ patients had heterozygous AIRE gene mutations; two of these were novel mutations (D312N in exon 8, and R471C in exon 12) that have not been reported to date and one of the patients had detectable serum IFN

The possible relevance of heterozygous AIRE gene mutations for the clinical manifestation of $\mathrm{CH}$ was assessed in a study of 15 first-degree relatives of our $\mathrm{CH}$ patients who carried 
heterozygous AIRE gene mutations. 10 first-degree relatives were found to carry the mutations, however, none had $\mathrm{CH}$ or any other components of APECED. This suggests that heterozygous AIRE gene mutations found in our patients with $\mathrm{CH}$ may not be relevant for the clinical manifestation of $\mathrm{CH}$. Furthermore these observations suggest that the heterozygous AIRE gene mutations may not be relevant in the etiopathogenesis of isolated $C H$.

Our study showed that in patients with sporadic $\mathrm{CH}$ and in their first-degree relatives $\underline{t h e}$ prevalence of AIRE gene mutations is high and it is much higher than in any other group of patients without APECED studied to date $(29,30)$.

In our study we did not find a relationship between $\mathrm{CH}$ and class II HLA haplotypes and this contrasts with previously reported significant association between HLA DRB*01 and *09 with $\mathrm{CH}$ not associated with APECED (11). The limited number of patients could be partly responsible for not finding the association in our study, but it also may well be that the differences in the geographical origin of the patients in this and the previous study account for the discrepancy.

Recently NALP5Abs have been identified as immunological markers of CH associated with APECED (7). In our study only one patient (Patient 9; Table 2) who carried a novel heterozygous AIRE mutation had detectable NALP5 Abs. This patient was also positive for IFN $\mathrm{A}$ Abs reported to be characteristic for APECED (6). Consequently, the long-term follow-up of this patient who presents the three APECED markers may provide valuable insights as to whether the combination of genetic and immunological markers may be helpful in prediction of development of APECED in the future (31). 
Overall, long term follow-up of our $\mathrm{CH}$ patients should be helpful in assessing the value of genetic and immunological markers in the classification of patients to various forms of APS and assessing possible risks of developing other autoimmune diseases in the future.

Our study has shown that a proportion of patients with $\mathrm{CH}$ (isolated or associated with autoimmune diseases not included in APECED) carry homozygous or heterozygous AIRE gene mutations. In particular, patients with $\mathrm{CH}$ and homozygous AIRE mutations may be at risk of developing APECED. Furthermore, it may be helpful to identify patients with $\mathrm{CH}$ and heterozygous AIRE mutations in order to develop strategies to prevent transmission of APECED in the general population through genetic testing and counselling of prospective parents.

Consequently, analysis of AIRE gene mutations together with serum autoantibody profile should be helpful in the assessment of patients with $\mathrm{CH}$ in particular in young women with autoimmune diseases other than $\mathrm{AD}$ or $\mathrm{CC}$.

\section{ACKNOWLEDGMENTS}

This study was supported in part by a grant from the European Union Sixth Framework Programme, the EurAPS project: Autoimmune Polyendocrine Syndrome type I-a rare disorder of childhood as a model for autoimmunity, contract number 2005-005223, and in part by a grant from the European Union Seventh Framework Programme, the Euradrenal project: Pathophysiology and Natural Course of Autoimmune Adrenal Failure in Europe. Grant Agreement No. 2008-201167. 


\section{TABLE LEGENDS}

Table.1 AIRE gene PCR and sequencing primers

AIREF1-14 = Forward primers for AIRE gene exons 1-14

AIRER1-14 = Reverse primers for AIRE gene exons 1-14

$\mathrm{Ta}=$ Annealing temperature for the PCR reactions

Table 2. Characteristics of 24 patients with $\mathrm{CH}$ in the study.

$(\mathrm{CH}=$ chronic hypoparathyroidism, $\mathrm{CT}=$ chronic thyroiditis, $\mathrm{GH}=$ growth hormone, $\mathrm{CAG}=$ chronic atrophic gastritis, PCA $=$ parietal cell autoantibodies, GADAbs $=$ glutamic acid decarboxylase autoantibodies, ICA= islet-cell autoantibodies, NALP5Abs= NACHT leucinerich-repeat protein 5 autoantibodies, IFN $\omega$ Abs =interferon omega autoantibodies, IFA= intrinsic factor autoantibodies, TMHAbs $=$ thyroid microsomal haemoagglutinating autoantibodies, $\quad$ TgHAbs $=$ thyroglobulin haemoagglutinating autoantibodies, $\mathrm{ANA}=$ antinuclear autoantibodies, ${ }^{1}$ AIRE gene mutations are shown in bold).

Table 3. Characteristics of first-degree relatives of patients with $\mathrm{CH}$ and AIRE gene mutations. 


\section{Page 17 of 23}

Table 1.

\begin{tabular}{|c|c|c|c|}
\hline Primer name & $\begin{array}{l}\text { PCR product } \\
\text { Size (bp) }\end{array}$ & $\mathrm{Ta}$ & Sequence \\
\hline AIREF 1 & \multirow{2}{*}{276} & \multirow[t]{2}{*}{$55^{\circ} \mathrm{C}$} & 5'CGTGCCAGTGTCCCGGGACCCACC $3^{\prime}$ \\
\hline AIRER1 & & & 5'GGGCGGGGTTCCTCCTGGAACTTCC3' \\
\hline AIREF2 & \multirow{2}{*}{342} & \multirow[t]{2}{*}{$65^{\circ} \mathrm{C}$} & 5' GTTAGAAGTTGGTCCCCTTCC3' \\
\hline AIRER2 & & & 5'GCTGAGCAGGTGACAGCA3' \\
\hline AIREF3 & \multirow[t]{2}{*}{498} & \multirow[t]{2}{*}{$59^{\circ} \mathrm{C}$} & 5'ACCCTACCCCTGGAGAAAAC3' \\
\hline AIRER3 & & & 5'AGTGCTGGGTAGTCCCTTTG3' \\
\hline AIREF 4 & \multirow[t]{2}{*}{293} & \multirow[t]{2}{*}{$62^{\circ} \mathrm{C}$} & 5' CAAAGGGACTACCCAGCACT3' \\
\hline AIRER4 & & & 5CCCCTAGGACAGGGTCTCA3' \\
\hline AIREF 5 & \multirow[t]{2}{*}{258} & \multirow[t]{2}{*}{$62^{\circ} \mathrm{C}$} & 5'GCCTGCTTCTGGCATAGAGT3' \\
\hline AIRER5 & & & 5'GTGGTCCTCCTTCCATCTTG3' \\
\hline AIREF6 & \multirow[t]{2}{*}{291} & \multirow[t]{2}{*}{$60^{\circ} \mathrm{C}$} & 5'CCTGGGGCCTACACGACT3' \\
\hline AIRER6 & & & 5'CCAGAGGCAACGCTGTTC3' \\
\hline AIREF 7 & \multirow{2}{*}{292} & \multirow[t]{2}{*}{$60^{\circ} \mathrm{C}$} & 5'CTCTGGGGGACTGGCTCT3' \\
\hline AIRER7 & & & 5' CCCTGAGTGCCCAGGTAAA3' \\
\hline AIREF 8 & \multirow[t]{2}{*}{293} & \multirow[t]{2}{*}{$62^{\circ} \mathrm{C}$} & 5'AAGGAGGTGGCTCTCAGGA3' \\
\hline AIRER8 & & & 5'TTCCATCTTGGATGGGAGAG3' \\
\hline AIREF9 & \multirow{2}{*}{251} & \multirow[t]{2}{*}{$60^{\circ} \mathrm{C}$} & 5'CGCTGTCTTGTTCTGCATGT3' \\
\hline AIRER9 & & & 5'ACAGGACTCCAGGGGACAG3' \\
\hline AIREF10 & \multirow[t]{2}{*}{300} & \multirow[t]{2}{*}{$63^{\circ} \mathrm{C}$} & 5' CACTGACTCCTGGGTGGTG3' \\
\hline AIRER10 & & & 5'GTAGTCCTGGGCTCCTTGAA3' \\
\hline AIREF11 & \multirow{2}{*}{279} & \multirow{2}{*}{$61^{\circ} \mathrm{C}$} & 5' TCGGGTTGAGCTACATTTCC3' \\
\hline AIRER11 & & & 5' GTGTGGTTGTGGGCTGTATG3' \\
\hline AIREF12 & \multirow[t]{2}{*}{247} & \multirow[t]{2}{*}{$62^{\circ} \mathrm{C}$} & 5'GAGGTGGCACTCCTGCTC3' \\
\hline AIRER12 & & & 5'TCTGCCCTGAGATGTGCTC3' \\
\hline AIREF13 & \multirow[b]{2}{*}{294} & \multirow[b]{2}{*}{$63^{\circ} \mathrm{C}$} & 5'ATCTCAGTGTGGGGGAAACA3' \\
\hline AIRER13 & & & 5'CTGAGTTTCCACGGCTCAAG3 \\
\hline AIREF14a & \multirow{2}{*}{344} & \multirow[t]{2}{*}{$62^{\circ} \mathrm{C}$} & 5'GGAGGTTCTCACCGTCACTC3' \\
\hline AIRER1 4a & & & 5'AGTAGGTCACCAGGCAAGGA3' \\
\hline AIREF 1 4b & \multirow{2}{*}{364} & \multirow{2}{*}{$59^{\circ} \mathrm{C}$} & 5' AATTAAACCCTGCCCCACTT3' \\
\hline AIRER14 & & & 5'TCCATTCAGGAAGCTGGAAC $3^{\prime}$ \\
\hline
\end{tabular}


Table 2.

\begin{tabular}{|c|c|c|c|c|c|c|c|c|c|}
\hline Patients & Gender & $\begin{array}{l}\text { Actual } \\
\text { Age }\end{array}$ & $\begin{array}{l}\text { Age at onset } \\
\text { of } \mathrm{CH}\end{array}$ & Other clinical diseases & Auto Abs & IFN $\omega$ Abs & $\begin{array}{l}\text { AIRE gene pattern } \\
\text { (Mutations and/or } \\
\text { polymorphisms) }\end{array}$ & $\begin{array}{c}\text { HLA } \\
\text { DRB1* }\end{array}$ & $\begin{array}{c}\text { HLA } \\
\text { DRB1* }\end{array}$ \\
\hline 1. & $\mathrm{~F}$ & 41 & 30 & no & neg & neg & S196,G227,A399 & 12 & 13 \\
\hline 2. & $\mathrm{~F}$ & 21 & 2 & $\begin{array}{l}\text { Hypergonadotropic } \\
\text { hypogonadism }\end{array}$ & neg & positive & $\begin{array}{c}\text { R257X/R257X, } \\
\text { S196 }\end{array}$ & 14 & - \\
\hline 3. & $\mathrm{~F}$ & 4 & 4 & no & neg & positive & $\begin{array}{c}\text { R203X,IVS9+5G>T, } \\
\text { S196,A399 } \\
\end{array}$ & 11 & 15 \\
\hline 4. & $\mathrm{~F}$ & 5 & 4 & no & neg & positive & $\begin{array}{c}\text { W78R/W78R, } \\
\text { S196,A399 }\end{array}$ & 13 & 14 \\
\hline 5. & $\mathrm{~F}$ & 11 & 9 & no & neg & neg & S196,A399,S411,D526 & 01 & 08 \\
\hline 6. & $\mathrm{~F}$ & 63 & 63 & no & neg & neg & S196,G227 & 01 & 15 \\
\hline 7. & $\mathrm{~F}$ & 37 & 22 & no & neg & neg & S196,A399,D526 & 13 & - \\
\hline 8. & $\mathrm{~F}$ & 30 & 14 & $\begin{array}{l}\text { Epilepsy, } \\
\text { goiter }\end{array}$ & $\begin{array}{l}\text { GADAbs } \\
\text { ANA }\end{array}$ & neg & IVS9,A399 & 04 & 13 \\
\hline 9. & $\mathrm{~F}$ & 20 & 14 & CT & $\begin{array}{l}\text { TMHAbs } \\
\text { ICA,GADAbs, } \\
\text { NALP5Abs }\end{array}$ & positive & $\begin{array}{c}\text { D312N, } \\
\text { S196,IVS9,G387,D526 }\end{array}$ & 10 & 11 \\
\hline 10. & $\mathrm{M}$ & 33 & 29 & no & TMHAbs & neg & A399,D526 & 03 & - \\
\hline 11. & $\mathrm{~F}$ & 19 & 15 & no & $\begin{array}{c}\text { ICA, } \\
\text { GADAbs }\end{array}$ & neg & S196,G227,D526 & 04 & 11 \\
\hline 12. & $\mathrm{~F}$ & 75 & 20 & no & PCA,IFA & neg & $\begin{array}{c}\text { P526L, } \\
\text { A33,A399 }\end{array}$ & 04 & 16 \\
\hline 13. & $\mathrm{~F}$ & 70 & 65 & CAG & neg & neg & S196,S278R,IVS9,A399,D526 & 03 & 07 \\
\hline 14. & $\mathrm{~F}$ & 34 & 26 & $\mathrm{CT}$, Psoriasis & PCA & neg & $\begin{array}{c}\text { R471C, } \\
\text { S196,IVS9,A399,D526 } \\
\end{array}$ & 13 & - \\
\hline 15. & $\mathrm{M}$ & 21 & 17 & GH defect & neg & neg & A399,D526 & 11 & 13 \\
\hline 16. & $\mathrm{~F}$ & 47 & 46 & no & GADAbs & neg & $\begin{array}{c}\text { A33A,G227,S278R,A399, } \\
\text { D526 }\end{array}$ & 01 & 13 \\
\hline 17. & $\mathrm{M}$ & 36 & n.d. & no & TMHAbs & neg & S196,S278R,A399,D526 & 03 & 14 \\
\hline 18. & $\mathrm{~F}$ & 63 & 31 & no & TgHAbs & neg & S196,IVS9,D526 & 11 & 13 \\
\hline 19. & $\mathrm{~F}$ & 7 & 5 & no & PCA & neg & A399,D526 & 04 & 14 \\
\hline 20. & $\mathrm{M}$ & 41 & n.d. & no & $\begin{array}{l}\text { TMHAbs, } \\
\text { TgHAbs }\end{array}$ & neg & S196,IVS9,A399,D526 & 01 & 11 \\
\hline 21. & $\mathrm{~F}$ & 13 & 11 & no & 18्ष्ठHAbs & neg & S196,G227,A399,S411,D526 & 11 & 13 \\
\hline 22. & $\mathrm{~F}$ & 51 & 44 & Graves' disease & neg & neg & G227,IVS9 & 07 & - \\
\hline 23. & F. & 49 & 1 & no & neg & neg & S196, A399, D526 & 07 & 11 \\
\hline 24. & M & 41 & 36 & no & neg. & neg & G227,IVS9,D526 & 13 & - \\
\hline
\end{tabular}


Table 3.

\begin{tabular}{|c|l|l|l|l|}
\hline Case & $\begin{array}{l}\text { First-degree } \\
\text { relative }\end{array}$ & $\begin{array}{l}\text { AIRE gene } \\
\text { mutations }\end{array}$ & Clinical diseases & Other Abs \\
\hline $\mathbf{2}$ & mother & R257X & absent & neg \\
\hline & father & R257X & absent & neg \\
\hline & brother & no mutations & absent & neg \\
\hline $\mathbf{3}$ & mother & R203X & absent & neg \\
\hline & father & IVS9+5G $>T$ & Chronic Thyroiditis & neg \\
\hline & brother & IVS9+5G>T & absent & neg \\
\hline & sister & IVS9+5G $>T$ & absent & neg \\
\hline & sister & no mutations & absent & neg \\
\hline $\mathbf{4}$ & mother & W78R & Chronic Thyroiditis & neg \\
\hline & father & W78R & absent & neg \\
\hline $\mathbf{9}$ & mother & no mutations & Chronic Thyroiditis & GADAbs \\
\hline & father & D312N & Chronic Thyroiditis & GADAbs \\
\hline & sister & no mutations & absent & neg \\
\hline $\mathbf{1 4}$ & mother & R471C & absent & PCA \\
\hline & father & no mutations & lung cancer & neg \\
\hline
\end{tabular}




\section{REFERENCES}

1) Ahonen, P., Myllarniemi, S., Sipila, I., \& Perheentupa, J. (1990) Clinical variation of autoimmune polyendocrinopathy-candidiasis-ectodermal dystrophy (APECED) in a series of 68 patients. The New England Journal of Medicine, 322, 1829-1836.

2) Neufeld, M., \& Blizzard, R.M. (1980) Polyglandular autoimmune diseases. In: Formatted: Right: $-4.7 \mathrm{pt}$ Symposium on Autoimmune Aspects of Endocrine Disorders, (eds A. Pinchera, D. Doniach, G.F. Fenzi, \& L. Baschieri), Academic Press,, New York, pp. 357-365.

3) Betterle, C., Greggio, N.A., \& Volpato, M. (1998) Autoimmune polyglandular syndrome Type 1. The Journal of Clinical Endocrinology and Metabolism 83, 1049-1055.

4) Perheentupa J. Autoimmune polyendocrinopathy-candidiasis-ectodermal dystrophy. (2006) The Journal of Clinical Endocrinology and Metabolism 91, 2843-2850.

5) Betterle, C., \& Presotto, F. (2008). Autoimmune Polyglandular Syndromes (APS) or Multiple Autoimmune Syndromes (MAS). In: The Handbook of Systemic Autoimmune Diseases (eds S.E. Walker, \& L.J. Jara). Academic Press (Elsevier Ltd.), London, Volume 9, pp 135-148.

6) Husebye, E.S., Perheentupa J., Rautemaa R., Kampe O. (2009) Clinical manifestations and management of patients with autoimmune polyendocrine syndrome type I. Journal of Internal Medicine 265, 514-529.

7) Alimohammadi, M., Björklund, P., Hallgren, A., Pöntynen, N., Szinnai, G., Shikama, N., Keller, M.P., Ekwall, O., Kinkel, S.A., Husebye, E.S., Gustafsson, J., Rorsman, F., Peltonen, L., Betterle, C., Perheentupa, J., Akerström Westin, G., Scott. H.S., Holländer, G.A., \& Kämpe, O. (2008) Autoimmune polyendocrine syndrome type 1 and NALP5, a parathyroid autoantigen. The New England Journal of Medicine 358, 1018-1028.

8) Betterle, C. (2006) Parathyroid and autoimmunity. Annales d'Endocrinology (Paris) 67, $147-54$.

9) Goswami, R., Marwaha, R.K., Goswami, D., Gupta, N., Ray, D., Tomar, N., Singh, S. (2006) Prevalence of thyroid autoimmunity in sporadic idiopathic hypoparathyroidism in comparison to type 1 diabetes and premature ovarian failure. The Journal of Clinical Endocrinology and Metabolism 91, 4256-42599.

10) Goswami, R., Brown, E.M., Kochupillai, N., Gupta, N., Rani, R., Kifor, O., \& Chattopadhyay, N. (2004) Prevalence of calcium sensing receptor autoantibodies in patients with sporadic idiopathic hypoparathyroidism. European Journal of Endocrinology 150, 9-18. 
11) Goswami, R., Gupta, N., Ray, D., Tomar, N., Sarin, R., \& Vupputuri, M.R. (2005) Polymorphisms at $+49 \mathrm{~A} / \mathrm{G}$ and CT60 sites in the 3'UTR of the CTLA-4 gene and APECED-related AIRE gene mutations analysis in sporadic idiopathic hypoparathyroidism. International Journal of Immunogenenetics 32, 393-400.

12) Cervato, S., Mariniello, B., Lazzarotto, F., Morlin, L., Zanchetta, R., Radetti, G., De Luca, F., Valenzise, M., Giordano, R., Rizzo, D., Giordano, C., \& Betterle, C. (2009) Evaluation of the AIRE gene mutations in a cohort of Italian patients with autoimmunepolyendocrinopathy-candidiasis-ectodermaldystrophy (APECED) and in their relatives. Clinical Endocrinology 70, 421-428.

13) Olerup, O., \& Zetterguist, H. (1993) DR "low resolution" PCR-SSP typing: a correction and an update. Tissue Antigens 41, 119-134.

14) Di Mario, U., Betterle, C., Dondero, F., Fenzi, G.F., Mariotti, S., \& Trimarchi, F. on behalf of the Immunoendocrinology Study Group of the Italian Society of Endocrinology and participating laboratories (1994). Italian serum exchange workshop for the standardization of organ specific autoantibodies. 17, 355-65.

15) Tanaka, H., Perez, M.S., Powell, M., Sanders, J.F., Sawicka, J., Chen, S., Prentice, L., Asawa, T., Betterle, C., Volpato, M., Rees Smith, B., \& Furmaniak, J. (1997) Steroid 21-hydroxylase autoantibodies: measurements with a new immunoprecipation assay. The Journal of Clinical Endocrinology and Metabolism 82, 1440-1446.

16) Adolf, G.R., Frühbeis, B., Hauptmann, R., Kalsner, I. Maurer-Fogy, I. Ostermann, E. Patzelt, E. Schewendenwein, R., Sommergruber, W., Zöphel, A. (1991) Human interferon $\omega 1$ : isolation of the gene, expression in Chinese hamster ovary cells and characterization of the recombinant protein. Biochimica et Biophysica Acta 1089, 167174.

17) Scott, H.S., Heino, M., Peterson, P., Mittaz, 1., Lalioti, M.D., Betterle, C., Cohen, A., Seri, M., Lerone, M., Romeo, G., Collin, P., Salo, M., Metcalfe, R., Weetman, A., Papasavvas, M.,P., Rossier, C., Nagamine, K., Kudoh, J., Shimizu, N., Krohn, K.J., Antonarakis, S.E. (1998) Common mutations in Autoimmune PolyendocrinopathyCandidiasis-Ectodermal Dystrophy patients of different origins. Molecular Endocrinology 12, 1112-1119.

18) De Luca, F., Valenzise, M., Alaggio, R., Arrigo, T., Crisafulli, G., Salzano, G., Cervato, S., Mariniello, B., Lazzarotto, F., \& Betterle, C. (2008) Sicilian family with autoimmune polyendocrinopathy-candidiasis-ectodermal dystrophy (APECED) and lethal lung 
disease in one of the affected brothers. European Journal of Pediatrics 167, 12831288.

19) Meloni, A., Fiorillo, E., Corda, D., Perniola, R., Cao, A., \& Rosatelli, M.C. (2005) Two novel mutations of the AIRE protein affecting its homodimerization properties. Human Mutation 25, 319-326.

20) Bjorses, P., Halonen, M., Palvimo, J.J., Kolmer, M., Aaltonen, J., Ellonen, P., Perheentupa, J., Ulmanen, I., \& Peltonen L. (2000) Mutations in the AIRE gene: effects on subcellular location and transactivation function of the autoimmune polyendocrinopathy-candidiasis ectodermal dystrophy protein. The American Journal of Human Genetics 66, 378-392.

21) Asland, R., Gibson, T., \& Stewart, A.F. (1995) The PHD finger implications for chromatin-mediated transcriptional regulation trends. Trends in Biochemical Science 20, 56-59.

22) Mathis, D., \& Benoist, C. (2007) A decade of AIRE. Nature Reviews Immunology 7, 645-650.

23) Meloni, A., Perniola, R., Faa, V., Corvaglia, E., Cao, A., \& Rosatelli, M.C. (2002) Delineation of the molecular defects in the AIRE gene in autoimmune polyendocrinopathy-candidiasis-ectodermal dystrophy patients from Southern Italy. The Journal of Clinical Endocrinology and Metabolism 87, 841-846.

24) Rosatelli, M.C., Meloni, A., Meloni, A., Devoto, M, Cao, A., Scott, H.S., Peterson, P., Heino, M., Krohn, K.J.E., Nagamine, K., Kudoh, J., Shimizu, N., \& Antonarakis, S.E. (1998) A common mutation in Sardinian autoimmune polyendocrinopathy-candidiasisectodermal-dystrophypatients. Human Genetics 103, 428-434.

25) Coco, G., Dal Pra, C., Presotto, F., Albergoni, M.P., Canova, C., Pedini, B., Zanchetta, R., Chen, S., Furmaniak, J., Rees Smith, B., Mantero, F., \& Betterle C. (2006) Estimated risk for developing autoimmune Addison's disease in patients with adrenal cortex autoantibodies. The Journal of Clinical Endocrinology and Metabolism 91, 1637-1645.

26) Boe, A., Knappskog, M., Myhre, A., Sorheim, J., \& Husebye, S. (2002) Mutational analysis of the autoimmune regulator (AIRE) gene in sporadic autoimmune Addison's disease can reveal patients with unidentified autoimmune polyendocrine syndrome type 1. European Journal of Endocrinology 146, 519-522.

27) Magitta, N.F., Pura, M., Wolff, A.S.B., Vanuga, P., Meager, A., Knappskog, P.M., \& Husebye, E.S. (2008) Autoimmune Polyendocrine Syndrome type I in Slovakia: 
1

2

3

4

5

6

7

8

9

10

relevance of screening patients with autoimmune Addison's disease. European Journal of Endocrinology 158, 705-709.

28) Podkrajsek, K.T., Milemkovic, T., Odink, R.J., Claasen-van der Grinten, H.L., Bratanic, N., Hovnik, T., \& Battelino, T. (2008) Detection of a complete AIRE gene deletion and two additional novel mutations in a cohort of patients with atypical variants of APS-1. European Journal of Endocrinology 159, 633-639.

29) Turunen, J.A., Wessman, M., Forsblom, C., Kilpikari, R., Parkkonen, M., Pontynen, N., Ilmarinen, T., Ulmanen, I., Peltonen, L., Groop, P.H. (2006) Association analysis of the AIRE and insulin genes in Finnish type 1 diabetic patients. Immunogenetics 58, 331338.

30) Meyer, G., Badenhoop, K (2002) Autoimmune regulator (AIRE) gene on chromosome 21: implications for autoimmune polyendocrinopathy-candidiasis-ectodermal dystrophy (APECED) any more common manifestations of endocrine autoimmunity. Journal of Endocrinological Investigation 25, 804-11.

31) Eisenbarth, G. (2008) Do NALP5 autoantibodies correlate to hypoparathyroidism? Nature Clinical Practice Endocrinology 4, 544-545. 